\title{
KEGIATAN TRANSFER PENGETAHUAN DENGAN METODE DRILL TERHADAP SISWA SEKOLAH DASAR NEGERI (SDN) BENGKAYANG DAERAH PERBATASAN
}

\author{
Priska Vasantan ${ }^{1 *}$, Helena Anggraeni ${ }^{1}$, Apriyon Yosef ${ }^{1}$, Arlianto Atet ${ }^{1}$, Panra $^{2}$ \\ ${ }^{\text {I} P r o d i ~ M a n a j e m e n, ~ S e k o l a h ~ T i n g g i ~ I l m u ~ M a n a j e m e n ~ S h a n t i ~ B h u a n a, ~ B e n g k a y a n g, ~ I n d o n e s i a ~}$ \\ ${ }^{2}$ Prodi Kewirausahaan, Sekolah Tinggi Ilmu Manajemen Shanti Bhuana, Bengkayang, Indonesia \\ * Penulis Korespodensi : priska@shantibhuana.ac.id
}

\begin{abstract}
Abstrak
Kabupaten Bengkayang merupakan salah satu kabupaten di daerah perbatasan dan baru terentaskan dari ketertinggalan namun di beberapa pelosok daerah masih tergolong tertinggal baik dalam dunia pendidikan, spiritual. Pendidikan merupakan salah satu aspek yang berperanan penting pada peningkatan kualitas sumber daya manusia pada era revolusi industri 4.0 ini melalui programnya yaitu Making Indonesia 4.0. Oleh karena itu, kegiatan pengabdian masyarakat ini dilaksanakan bertujuan untuk meningkatkan sumber daya manusia mulai dari pendidikan dasar. Kegiatan pendampingan ini dilakukan dengan metode drill dengan pelbagai latihan yang memotivasi keaktifan siswa berdasarkan kearifan lokal yang dimiliki sehingga memengaruhi proses transfer pengetahuan dan student learning center. Kegiatan pendampingan proses pembelajaran ini diberlakukan terhadap siswa kelas 4, 5 dan 6 khususnya pada mata pelajaran Matematika dan pengenalan Bahasa Inggris. Hasil kegiatan pengabdian masyarakat ini adalah diperolehnya metode pembelajaran yang lebih baik melalui metode drill serta penggunaan poster pembelajaran sehingga mempermudah transfer pengetahuan kepada siswa SDN ini. Metode pembelajaran ini dapat digunakan oleh pihak sekolah sehingga dapat meningkatkan hasil belajar siswa.
\end{abstract}

Kata kunci: Revolusi Industri 4.0; Making Indonesia 4.0; Transfer Pengetahuan.

\begin{abstract}
Bengkayang Regency is one of the regencies in the border area and has only been eliminated from underdevelopment, but in some areas the region is still classified as good in the world of education, spiritual. Education is one aspect that plays an important role in improving the quality of human resources in the era of the industrial revolution 4.0 through its program, Making Indonesia 4.0. Therefore, this community service activity is carried out aimed at increasing human resources starting from basic education. This mentoring activity is carried out by the drill method with various exercises that motivate student activity based on local wisdom that is owned so that it affects the process of knowledge transfer and student learning center. The learning process assistance activities are applied to students in grades 4, 5 and 6, especially in Mathematics and English introduction. The results of these community service activities are getting better learning methods through the drill method and the use of learning posters so as to facilitate the transfer of knowledge to these SDN students. This learning method can be used by the school so that it can improve student learning outcomes.
\end{abstract}

Keywords: Industrial Revolution 4.0; Making Indonesia 4.0; Knowledge Transfer. 


\section{PENDAhuluan}

Kabupaten Bengkayang merupakan salah satu kabupaten yang berbatasan langsung dengan Sarawak, Malaysia. Bengkayang memiliki luas hampir sama dengan luas pulau Bali yaitu 5396,3 $\mathrm{km}^{2}$ (Kabupaten Bengkayang, 2018) dengan penduduk yang berjumlah 5.016,7 ribu orang.

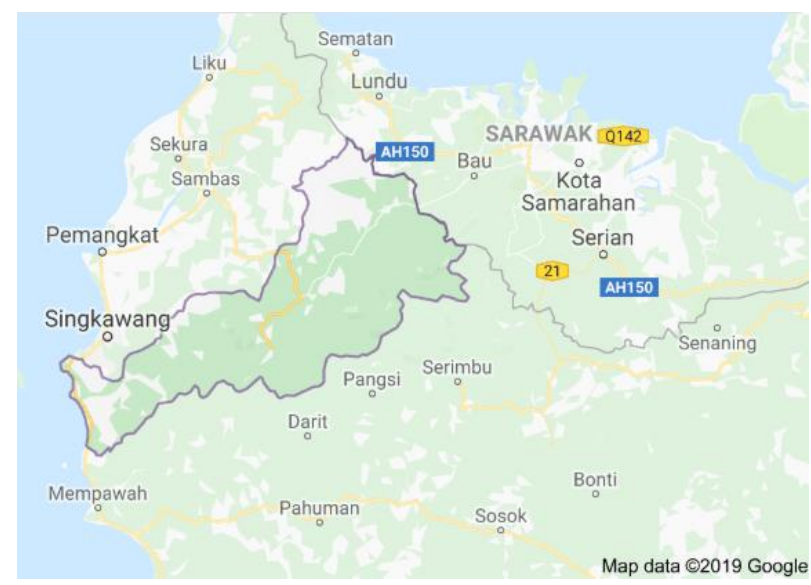

Gambar 1. Peta Bengkayang yang berbatasan langsung dengan Sarawak, Malaysia (sumber: Google).

Menurut Peraturan Presiden no 131 tahun 2015 tentang penetapan Daerah Tertinggal (Presiden Republik Indonesia, 2015), kabupaten Bengkayang merupakan salah satu daerah tertinggal baik dari segi pendidikan, ekonomi, sarana prasarana, dan lain sebagainya. Namun per Juli 2019, seiring perkembangan muncullah Keputusan Menteri Desa, Pembangunan Tertinggal dan Transmigrasi Indonesia (Menteri Desa, 2019) bahwa kabupaten Bengkayang telah terentaskan dari ketertinggalan. Keputusan ini masih belum mencakup pelosok kabupaten bengkayang seluruhnya karena beberapa desa pelosok masih ditemukan kualitas siswa yang sangat memprihatinkan sehingga dapat dikatakan masih belum siap secara sepenuhnya mencapai Making Indonesia 4.0 di era Revolusi Industri 4.0 ini.

Revolusi industri 4.0 (Rojko, 2017) merupakan tahapan keempat perkembangan dari revolusi industri. Perkembangan revolusi industri ini dapat dijabarkan sebagai berikut:

1) Revolusi industri 1.0 dimulai dari penggunaan mekanik atau mekanisasi pada generasi tahun 1800-an. Hal ini membawa transisi dari pekerjaan manual pada pekerjaan mekanik; sebagian besar adalah industri tekstil.

2) Revolusi 2.0 dipicu melalui elektrisasi yang memungkinkan produksi massal.

3) Revolusi industri 3.0 ditandai oleh digitalisasi dengan ion dari mikroelektronika dan otomasi. Revolusi industri ini memfasilitasi produksi yang fleksibel melalui jalur produksi dengan pemrogaman mesin, namun masih belum memiliki kefleksibilitasan akan kuantitas produksi.

4) Revolusi industri 4.0 yang dipicu oleh perkembangan teknologi informasi dan komunikasi yang berbasis teknologi dengan otomatisasi cerdas dari sistem fisikcyber yang memungkinkan produksi kustom massal fleksibel dan kefleksibilitasan dalam jumlah produksi. Jadi dapat dikatakan bahwa revolusi industri 4.0 lebih sering menggunakan teknologi informasi dan komunikasi.

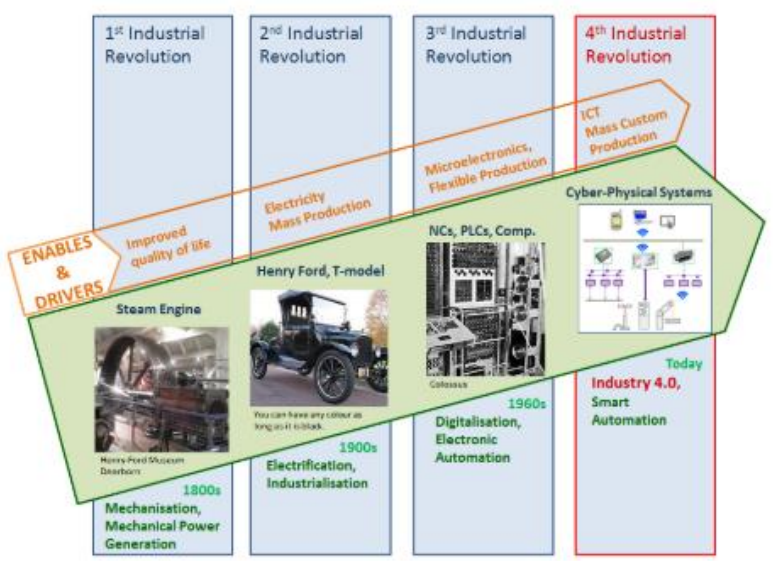

Gambar 2. Proses Revolusi Industri (Rojko, 2017).

Era revolusi Industri 4.0 ini terdapat program yang disebut education 4.0. Program ini merupakan program pendidikan yang diterapkan di era revolusi industri 4.0 ini. Education 4.0 menerapkan metode student centered learning dan blended learning (Shahroom \& Hussin, 2018). Metode student centered learning ini merupakan metode pembelajaran yang diorientasikan pada perkembangan siswa, sedangkan blended learning merupakan kombinasi metode e-learning (aplikasi, internet) dan face-to-face (pengajaran di kelas). Namun, pada SD ini belum siap menerima metode blended learning yang dikarenakan minimnya sara prasarana yang dimiliki.

Kualitas manusia di Kabupaten Bengkayang masih tergolong rendah. Menurut statistik kabupaten Bengkayang tahun 2018 (Kabupaten Bengkayang, 2018), Indeks Pembangunan Manusia (IPM) kabupaten Bengkayang adalah 65,99 berada di bawah IPM Provinsi Kalimantan Barat sebesar 66,26. Hal ini menyatakan bahwa kualitas manusia di kabupaten Bengkayang berada di bawah kualitas manusia di provinsi Kalimantan Barat. 
Tabel 1. Indeks Pembangunan Manusia di Provinsi Kalimantan Barat (Kabupaten Bengkayang, 2018).

\begin{tabular}{|l|c|}
\hline Kabupaten/Kota & $\begin{array}{c}\text { Indeks } \\
\text { Pembangunan } \\
\text { Manusia (IPM) }\end{array}$ \\
\hline Pontianak & 77.93 \\
\hline Singkawang & 70.25 \\
\hline Kubu Raya & 66.31 \\
\hline Kalimantan Barat & 66.26 \\
\hline Bengkayang & 65.99 \\
\hline Sambas & 65.92 \\
\hline Ketapang & 65.71 \\
\hline Sintang & 65.16 \\
\hline Landak & 64.93 \\
\hline Sanggau & 64.61 \\
\hline Melawi & 64.43 \\
\hline Kapuas Hulu & 64.18 \\
\hline Mempawah & 61.00 \\
\hline Sekadau & 63.04 \\
\hline Kayong Utara & 61.52 \\
\hline
\end{tabular}

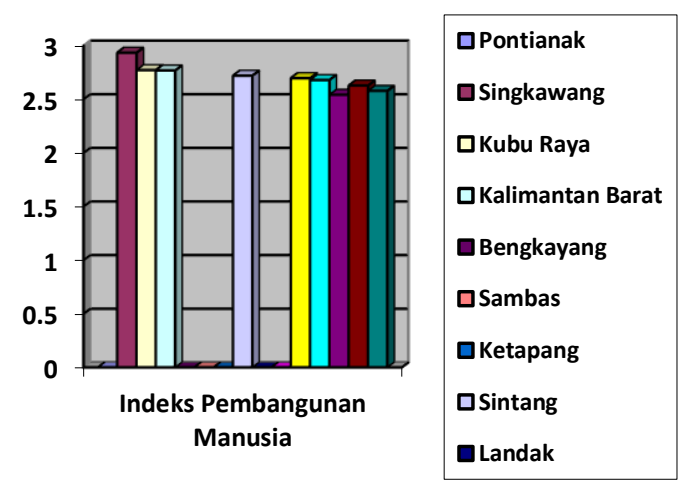

Gambar 3. Indeks Pembangunan Manusia.

Kabupaten Bengkayang merupakan salah satu kabupaten yang berbatasan langsung dengan Malaysia maka kualitas manusia seharusnya lebih kokoh dari pada daerah lainnya sebagai ketahanan ekonomi dan budaya. Oleh karena itu, kualitas sumber daya manusia sangat perlu ditingkatkan bukan hanya demi mencapai program Making Indonesia 4.0 namun sebagai ketahanan ekonomi dan budaya. Program Making Indonesia 4.0 (Hartarto, 2018).

Kementerian perindustrian ((BPPI), 2018) pada tanggal 4 April 2018 memulai luanching program Making Indonesia 4.0, yaitu program untuk menjadikan Indonesia sebagai top 10 ekonom di seluruh dunia pada tahun 20130. Saat ini Indonesia menduduki top 16 ekonom di seluruh dunia. Faktor yang memengaruhi Indonesia menjadi ekonom adalah Pendapatan Domestik Bruto (PDB) seperti peningkatan belanja konsumen, belanja pemerintah, investasi dan sebagai faktor pendorong pertumbuhan selanjutnya adalah ekspor neto.

Peningkatan produktivitas tenaga kerja Indonesia lebih rendah 46 persen dari Cina, perbandingan biaya tenaga kerja Indonesia lebih besar 62 persen, sedangkan peningkatan produktivitas Indonesia lebih rendah daripada peningkatan biaya tenaga kerja seperti pada gambar 4.

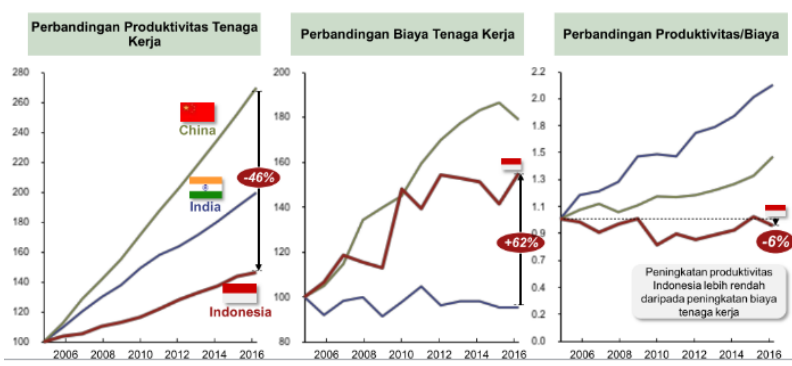

Gambar 4. Perbandingan Pertumbuhan Biaya dengan Produktivitas.

Kementerian perindustrian (BPPI, 2018) akhirnya menetapkan 10 prioritas nasional untuk mencapai Making Indonesia 4.0. Salah satu yang menjadi prioritas adalah peningkatan sumber daya manusia pada poin 7 sehingga Bengkayang yang merupakan daerah yang berbatasan langsung dengan Malaysia memiliki peranan sangat penting bagi Indonesia dalam program menuju Making Indonesia 4.0. Oleh karena itu, perlunya dilakukan tindakan bagi Bengakayang terutama meningkatkan sumber daya manusia melalui peningkatan pendidikan melalui perbaikan metode transfer pengetahuan.

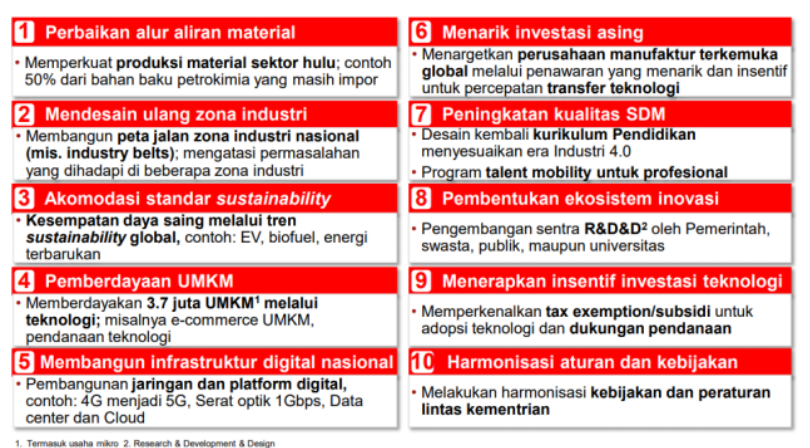

Gambar 5. Sepuluh Prioritas Nasional.

Pada penelitian sebelumnya, peneliti menemukan beberapa kerentanan yang terdapat di SDN di desa Tampe, kabupaten Bengkayang yaitu minimnya kualitas siswa, kualitas guru, sarana prasarana, dan kesadaran akan pentingnya pendidikan. Kualitas siswa di SD ini termasuk rendah seperti siswa kelas 4 masih belum bisa membaca dengan lancar, siswa kelas 6 masih belum hafal perkalian, pembagian dan penulisan angka mulai dalam bentuk ratusan, desimal dan juga belum mengerti tentang perhitungan volume dan luas geometri. Hal ini disinyalir 
karena kualitas guru yang mengajar tidak sesuai dengan keahliannya, metode pengajaran sebagai transfer pengetahuan antara guru ke siswa teacher oriented sehingga siswa sangat tergantung pada guru. Sarana perpustakaan yang tidak ada sehingga siswa jarang membaca buku dan tdak adanya budaya membaca. Demikian pula orang tua dan siswa memiliki kesadaran yang rendah akan pentingnya pendidikan demi masa depan sehingga seringkali siswa membolos dan mencari uang bahkan putus sekolah.

Berdasarkan data kemendagri, November 2018, pemerintah daerah telah mengucurkan dana pendidikan pada tahun 2018 yaitu sebesar Rp1.175,09M (11,8 persen) (Bengkayang, 2018), namun berdasarkan Kemendikbud Oktober 2018, alokasi anggaran bantuan Pemerintah (APBN) untuk SD $0,00 \mathrm{M}$ sehingga dana untuk mengembangkan pendidikan dasar tidak ada. Berdasarkan Dirjen GTK, November 2018, guru SD yang telah tersertifikasi sebesar 30,7 persen, kualifikasi guru SD $\geq$ D4/S1 sebesar 78,1 persen. Menurut data PDSPK bulan November 2018, siswa SD yang putus sekolah sebanyak 88 siswa dan yang mengulang sebanyak 1638 siswa. Hal ini menimbulkan keprihatinan di dunia pendidikan karena pendidikan dasar merupakan pembinaan dini yang sangat memengaruhi keberlangsungan pendidikan selanjutnya. Fenomena ini juga terjadi pada mahasiswa di kota Bengkayang, menurut penelitian sebelumnya 50 persen mahasiswa kabupaten Bengkayang tidak dapat menuliskan angka dalam bentuk ribuan, puluhan ribu dan seterusnya.

Peningkatan kualitas sumber daya manusia di daerah Bengkayang ini membutuhkan perhatian lebih terutama dalam pembinaan karakter dan pembinaan akademik mulai dari tingkat pendidikan dasar. Salah satu yang dapat dilakukan adalah memperbaharui proses tranfer pengetahuan dari guru ke siswa melalui metode pembelajaran yang diberikan terutama sesuai dengan era revolusi industri 4.0 ini.

Pengetahuan manusia (Su Luan \& Abu Bakar, 2008; Vasantan et al., 2016; Vasantan \& Manggu, 2019) dapat dibedakan menjadi dua yaitu tacit (pengetahuan yang dimiliki karena adanya pengalaman) dan eksplisit (pengetahuan yang ada dalam buku, media massa, media sosial, internet, dll.). Proses transfer pengetahuan yang diberikan oleh guru kepada siswa yaitu pengajaran langsung (tacit ke tacit), membuat bahan ajar (tacit ke eksplisit), menggunakan buku sebagai bahan ajar (eksplisit ke tacit), menggunakan media sosial atau internet dalam mendapatkan informasi baik oleh guru dan siswa (eksplisit ke tacit), dan lain sebagainya. Metode transfer pengetahuan ini sangatlah memengaruhi motivasi dan daya tangkap belajar siswa.

Kegiatan ini bertujuan untuk meningkatkan transfer pengetahuan Matematika dan perkenalan Bahasa Inggris terhadap siswa kelas 4, 5 dan 6 dalam mempersiapkan ujian akhir dan Ujian Nasional (UNAS) sesuai dengan permasalahan yang dimiliki oleh mitra.

Permasalahan mitra yang dihadapi adalah minimnya kualitas pengetahuan yang dimiliki oleh kelas 4, 5, dan 6 di SDN ini khususnya Matematika yang ditemukan oleh tim pelaksana melalui observasi dan wawancara yang mendalam dengan kepala sekolah, guru dan alumni SD ini. Permasalahan mitra lainnya adalah pelajaran bahasa Inggris yang belum pernah diberikan sebelumnya dikarenakan tidak adanya guru Bahasa Inggris. Oleh karena itu, tim pelaksana melaksanakan kegiatan pengajaran tambahan khusus pada hari Sabtu di luar jam pelajaran untuk mempersiapkan Ujian Akhir Nasional (UNAS) bagi kelas 6 dan ujian akhir semester bagi kelas 4 dan 5.

\section{METODE PELAKSANAAN}

Kegiatan ini menggunakan metode pembelajaran drill untuk Matematika dan Bahasa Inggris, dan video untuk pengenalan Bahasa Inggris. Pengajaran yang dilakukan setiap hari Sabtu selama 3 bulan ini dilaksanakan di kelas 4,5 dan 6 SDN dengan pengajar dari mahasiswa dan dosen. Metode Drill (Kumalasari, Studi, Informatika, Teknik, \& Ponorogo, 2016) merupakan metode pembelajaran dengan memberikan penjelasan dan latihanlatihan. Sedangkan video yang digunakan dalam pengajaran Bahasa Inggris adalah berupa pengenalan akan abjad, angka dan arti kata Bahasa Inggris.

Partisipasi mitra dalam kegiatan ini berupa penyediaan sarana dan prasarana yang menunjang kegiatan belajar mengajar seperti alat tulis dan ruang kelas. Rancangan pelaksanaan kegiatan seperti pada gambar 6 di bawah ini: 


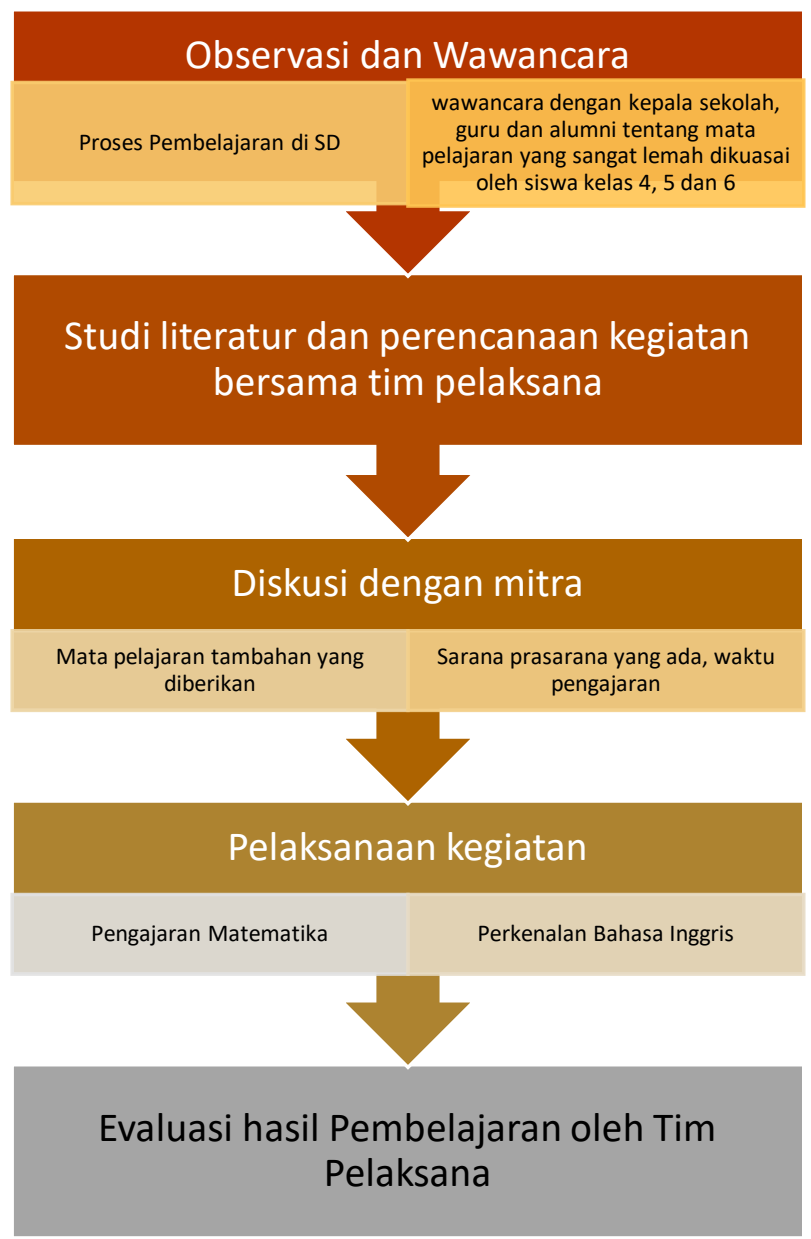

Gambar 6. Rancangan Pelaksanaan Kegiatan.

\section{HASIL DAN PEMBAHASAN}

Sebelumnya perlu diketahui bahwa pengabdian masyarakat ini merupakan hasil penelitian sebelumnya. Oleh karena urgensinya permasalahan yang dihadapi oleh mitra terkait pada kualitas sumber daya manusia sejak dini, maka peneliti melanjutkan dengan pengabdian masyarakat. Penelitian sebelumnya merupakan penelitian Dosen Pemula Hibah Dikti tahun pelaksanaan 2018 yang berjudul: "Pemerolehan Bahasa Kedua Anak Sebagai Dasar Pembelajaran Di Daerah Perbatasan". Pada akhir penelitian, peneliti menemukan beberapa permasalahan baru yang dihadapi oleh mitra yaitu minimnya kemampuan berhitung dan menulis angka ribuan, ratusan ribu dan seterusnya. Oleh karena itu peneliti menjawab urgensi permasalahan ini melalui pengabdian masyarakat yang didanai oleh kampus.

Kegiatan yang dilaksanakan ini telah memberikan dampak positif bagi siswa SDN ini, khususnya dalam persiapan UNAS dan UAS pada semester genap TA. 2018-2019 ini. Hal ini dapat diketahui oleh kemampuan siswa dalam menjawab dan mengerjakan tugas yang diberikan. Uraian berikut merupakan penjelasan hasil dari pengabdian masyarakat ini, yaitu sebagai berikut:
1) Observasi dan wawancara mendalam

Obrservasi dan wawancara yang berkelanjutan ini menemukan suatu poin yang berkenaan dengan metode pembelajaran yang diberikan kepada siswa. Ada beberapa hal yang ditemukan oleh tim pelaksana pada saat observasi dan wawancara, yaitu:

a. Metode teacher oriented sehingga siswa sangat bergantung pada guru yang mengampu pelajaran tersebut. Hal yang sering terjadi adalah jika guru berhalangan hadir maka seringkali jam pelajaran kosong dan siswa menggunakan waktu untuk bermain. Dengan demikian banyak waktu belajar yang tidak digunakan secara efektif dan efisien. Demikian pula dengan metode pembelajaran yang dilakukan dengan cara memberi materi dan minimnya latihan yang diberikan. Oleh karena itu, tim pelaksana memutuskan untuk menggunakan metode drill dengan memberikan banyak latihan pada membaca, matematika dan bahasa Inggris.

b. Menurut kepala sekolah dan beberapa guru, mata pelajaran yang sangat lemah adalah berhitung dan belum pernah mendapatkan pelajaran Bahasa Inggris dikarenakan tidak adanya guru yang mengajar Bahasa Inggris.

c. Pelajaran yang diberikan oleh tim pelaksana hanya bersifat tambahan, maka pelajaran diberikan pada hari Sabtu saat kelas sudah usai sehingga tidak mengganggu proses belajar mengajar utama sekolah.

d. Sarana yang disediakan oleh pihak sekolah adalah ruang kelas beserta spidol whiteboard dan satu aliran listrik untuk menyalakan LCD dan laptop yang dibawa oleh tim pelaksana. Hal ini dikarenakan minimnya prasarana yang dimiliki oleh sekolah ini.

e. Sehubungan dengan minimnya waktu dan kemampuan membaca siswa yang juga sangat minim, maka tim pelaksana melayani beberapa siswa SD yang mengikuti sekolah Minggu di gereja stasi Tampe.

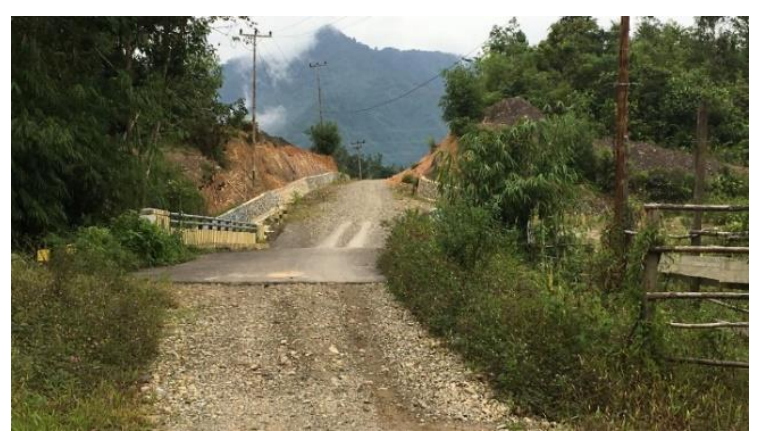

Gambar 7. Jalan Menuju Desa Tampe, Bengkayang. 
Pada dasarnya desa Tampe ini merupakan desa yang sedang dalam proses pembangunan jalan seperti yang tertera pada gambar 7. Namun saat kegiatan PKM ini dilakukan jalan menuju desa ini masih dalam bentuk jalan berkerikil sampai saat ini. Demikian pula pada gambar 8 dan 9 merupakan tempat pengabdian masyarakat ini berlangsung.

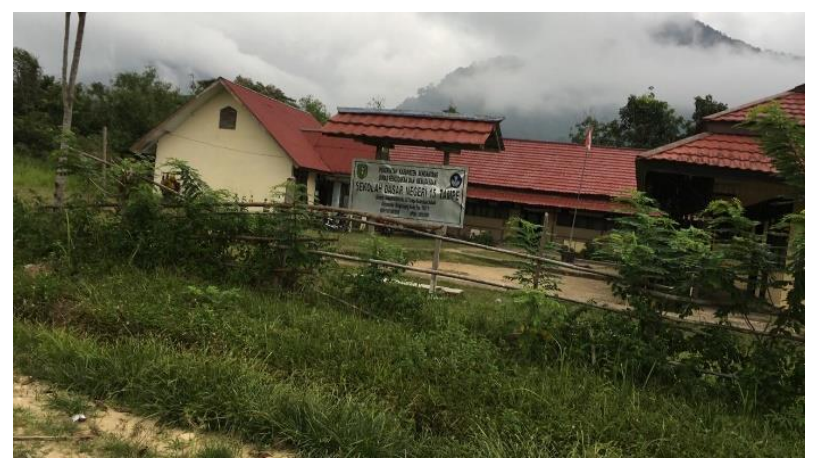

Gambar 8. SDN di Tampe, Bengkayang.

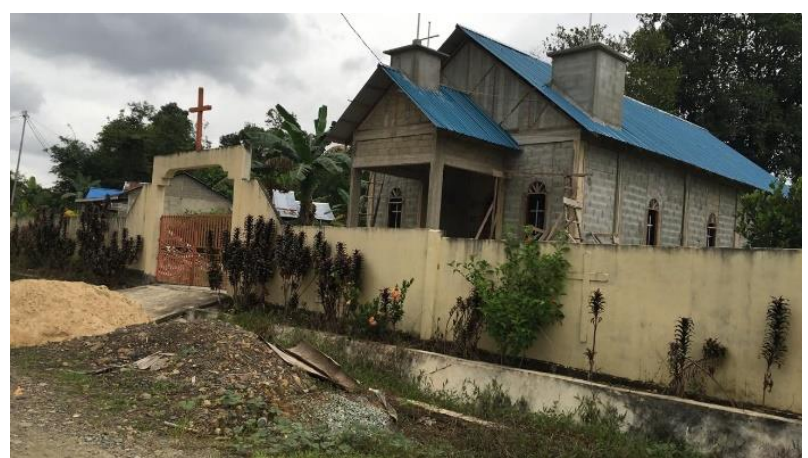

Gambar 9. Gereja Stasi St. Petrus, Tampe, Bengkayang.

2) Pelaksanaan Kegiatan Pengabdian Kepada Masyarakat (PKM)

Pelaksanaan PKM ini dilaksanakan di suatu tempat yaitu di SDN dan gereja stasi

a. Kegiatan pengajaran tambahan Matematika di SDN, Tampe, Bengkayang

Kegiatan PKM ini dilaksanakan terhadap 3 kelas yaitu kelas 4, 5, dan 6 yang bertujuan untuk mempersiapkan siswa menghadapi UAS dan UNAS. Hal ini dikarenakan minimnya kemampuan siswa dalam belajar matematika. Pengajaran ini di kelas 4 dan 5 diberikan oleh mahasiswa, sedangkan di kelas 6 oleh dosen yang merupakan tim pelaksana. Hal ini dilakukan karena adanya urgensi kemampuan berhitung seperti perkalian, pembagian, rumus bangun yang belum dikuasai oleh siswa baik kelas 4,5 , dan 6 yang pada umumnya sudah dikuasai oleh siswa sejak kelas 3. Oleh karena itu, tim pelaksana memberikan pengajaran dengan metode drill yaitu dengan pengajaran yang disertai pelbagai macam latihan yang diorientasikan kepada perkembangan siswa. Siswa diberikan pengajaran lalu tugas dan dibahas dengan cara mengerjakan soal sehingga siswa lebih mengerti dan menguasai materi.

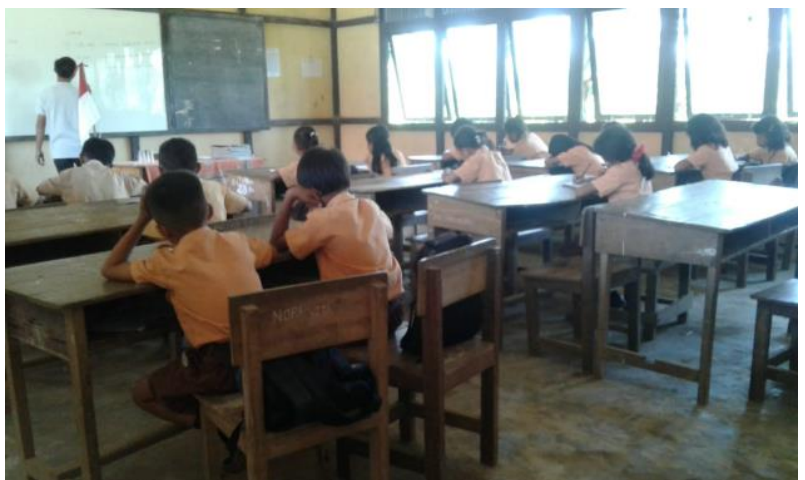

Gambar 10. Mahasiswa memberikan pengajaran penulisan angka ribuan, ratusan ribu dan seterusnya pada siswa SD kelas 4, Tampe.

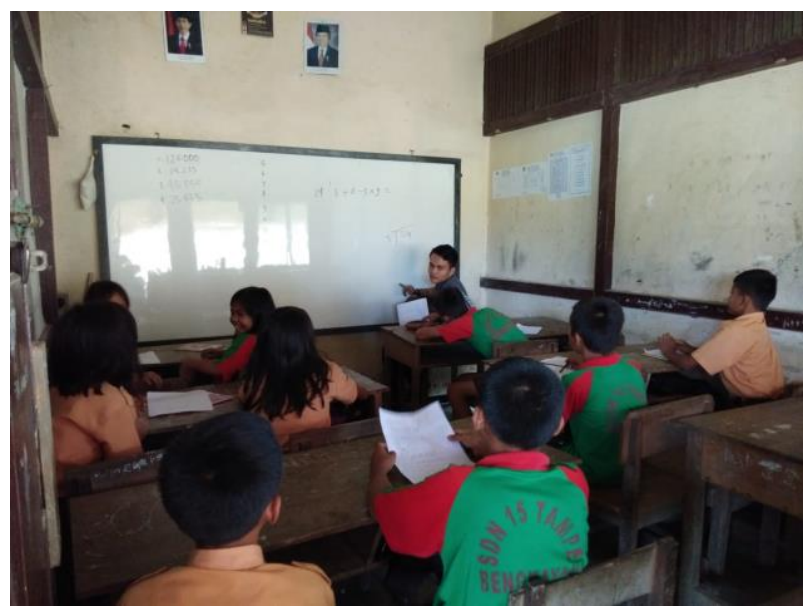

Gambar 11. Mahasiswa memberikan Pengajaran penulisan angka ribuan, ratusan ribu dan seterusnya pada siswa SD kelas 5, Tampe.

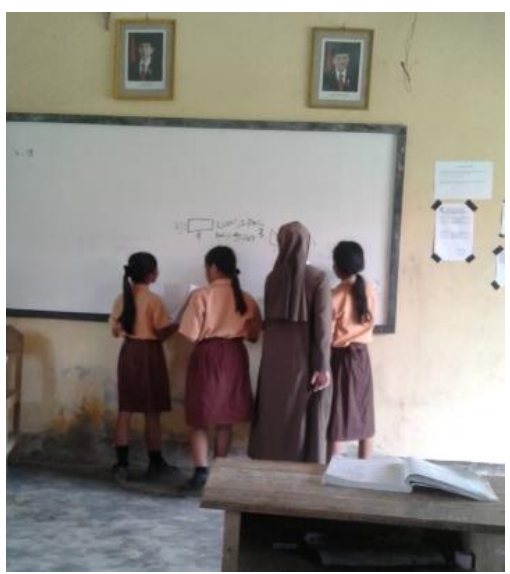

Gambar 12. Dosen memberikan pengajaran rumus geometri kepada siswa SD kelas 6, Tampe.

b. Kegiatan Perkenalan Bahasa Inggris kepada siswa SD kelas 4 dan 5 .

Kegiatan ini diberikan kepada kelas 4 dan 5 saja karena minimnya waktu yang ada dan fokus pembelajaran 
matematika pada kelas 6 maka perkenalan Bahasa Inggris ini tidak dapat diberikan pada kelas 6. Perkenalan bahasa Inggris ini diberikan melalui video anak-anak Bahasa Inggris tentang lagu abjad, angka, arti kata.

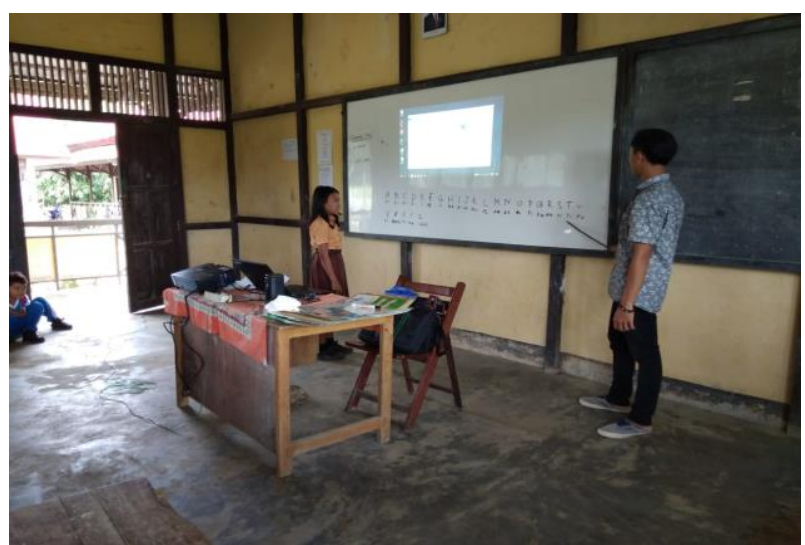

Gambar 13. Mahasiswa memberikan perkenalan Bahasa Inggris pada siswa SD kelas 4 dan 5, Tampe.

c. Kegiatan pembelajaran Bahasa Indonesia yaitu membaca, mendengarkan cerita.

Kegiatan ini diberikan dengan cara memberi kesempatan bagi siswa untuk menyukai membaca sehingga siswa dapat meningkatkan kompetensi membaca mereka. Pada sekolah Minggu, siswa diajarkan juga cara membaca kitab suci dengan intonasi dan ejaan yang benar. Bacaan cerita yang ada diberikan mampu meningkatkan motivasi siswa.

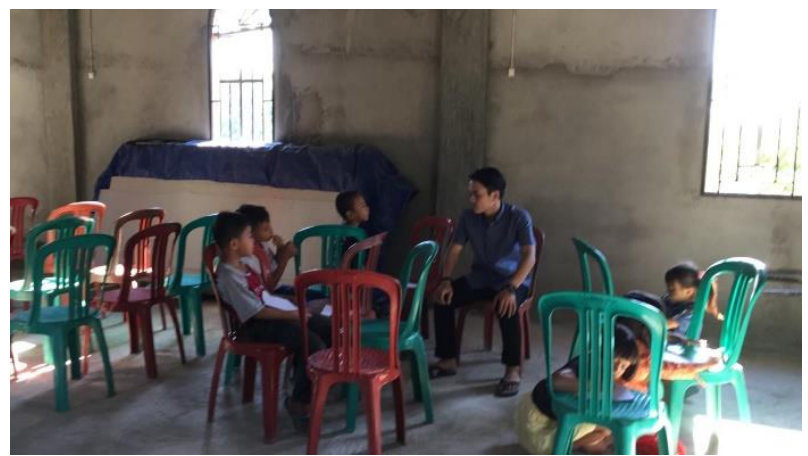

Gambar 14. Mahasiswa memberikan Pengajaran bahasa pada siswa SD kelas 4 di gereja stasi.

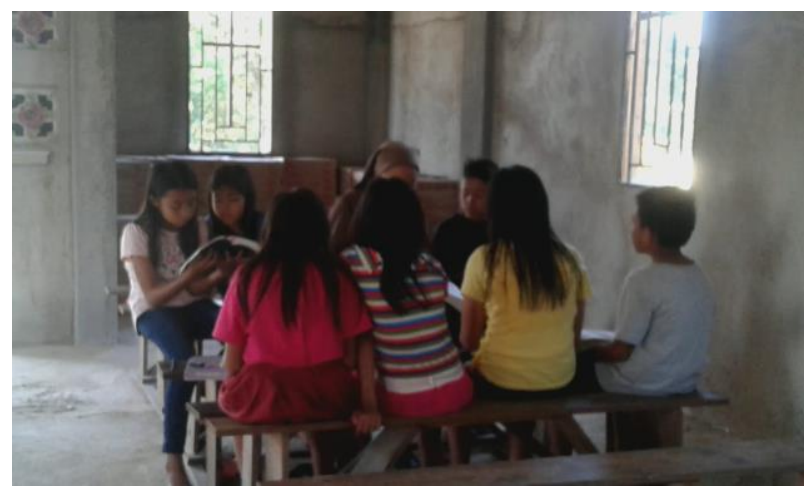

Gambar 15. Dosen memberikan membaca bahasa pada siswa SD kelas 5 dan 6 di gereja stasi.

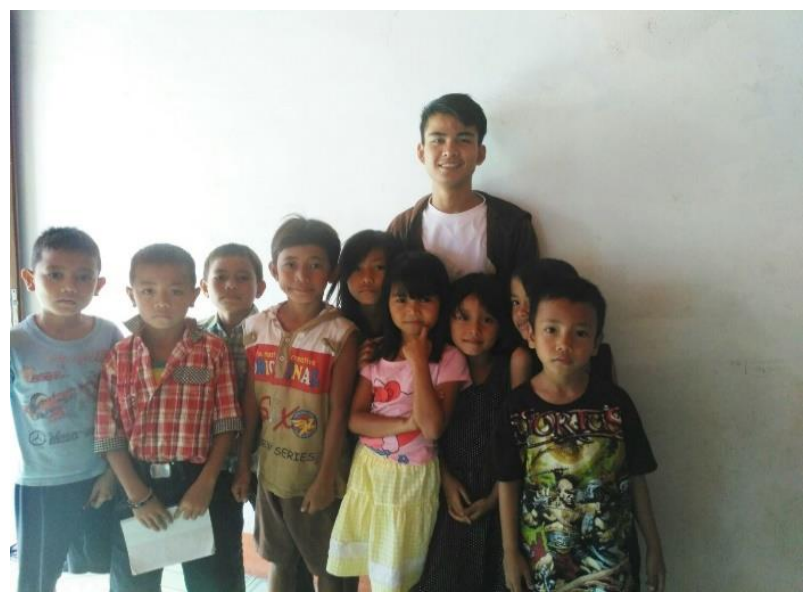

Gambar 16. Pengajaran Sekolah Minggu oleh mahasiswa.

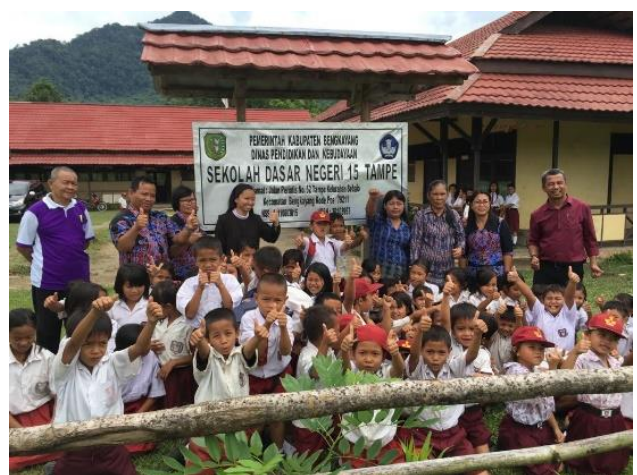

Gambar 17. Foto bersama Seluruh Civitas SDN Tampe

3) Evaluasi hasil pembelajaran

Evaluasi dan monitoring dilakukan oleh tim pelaksana setelah PKM harian dilaksanakan yang bertujuan untuk memperbaiki kinerja tim pelaksana sebagai evaluasi diri. Setelah pelaksanaan pengabdian masyarakat selesai maka tim pelaksana melakukan evaluasi secara keseluruhan sebagai hasil kegiatan PKM terutama perkembangan siswa.

Hasil evaluasinya adalah pelaksanaan pengabdian masyarakat ini berhasil dengan baik, hal ini nampak dari jawaban-jawabn siswa terhadap tiap materi Matematika yang diberikan, kecuali rumus geometri. Sampai wakt terakhir, siswa tidak termotivasi untuk belajar geometri ini dikarenakan menurut mereka tidak menarik. Setelah dievaluasi lebih mendalam melalui wawancara seorang alumni SD dan beberapa siswa ini, dapat disimpulkan bahwa guru yang memberikan materi inipun kurang menguasai materi geometri ini.

Pelaksanaan kegatan perkenalan Bahasa Inggris sangatlah menarik perhatian siswa bahkan siswa kelas 1, 2 dan 3 di bawah juga ikut duduk memperhatikan (pada gambar 10). 
Hal ini dikarenakan metode video yang belum pernah dilihat oleh anak-anak di tampe ini. Hal ini menjadi daya tarik sendiri dalam metode pembelajaran.

Pelaksanaan kegiatan pembelajaran membaca di sekolah Minggu yang terletak di gereja stasi St. Petrus ini tidak dapat diikuti oleh semua siswa, namun ada perkembangan dalam cara membaca siswa yang ikut serta dalam belajar ini seperti adanya intonasi, kelancaran membaca/mengeja. Proses transfer pengetahuan pada pendidikan di SDN Tampe ini juga dipengaruhi oleh beberapa faktor lain yaitu kearifan lokal, kesadaran akan pentingnya pendidikan, dan lain sebagainya, sehingga permasalahan mitra sebenarnya cukup kompleks.

Kearifan lokal yang berlaku pada desa ini adalah mengutamakan acara adat sehingga absen dari sekolah, sebagian besar penduduk adalah petani yang seringkali menantikan hasil panen dengan menghabiskan waktu untuk menoreh karet atau duduk bercengkerama dengan tetangga. Selain itu, penduduk juga terbiasa mendapatkan sayur di hutan sehingga sudah terbiasa dengan segala sesuatu yang sudah disediakan alam dan hal ini memengaruhi dalam daya juang siswa, guru maupun orang tua.

Mayoritas orang tua berpendidikan hingga SD saja sehingga kesadaran akan pentingnya pendidikan anaknya sangat rendah. Hal ini juga nampak pada hasil wawancara beberapa orang tua, guru dan kepala sekolah yang menyatakan bahwa orang tua memiliki pemeikiran bahwa proses tranfer pengetahuan adalah semata-mata tugas sekolah, di luar jam sekolah anak-anak mereka dibiarkan melakukan aktivitas sehari-hari entah itu bermain, bekerja atau belajar tanpa pendampingan orang tua. Padahal seharusnya pendidikan yang paling penting adalah pendidikan yang berasal dari rumah. Demikian halnya, seringkali siswa absen dari sekolah karena orang tua dan anak memiliki pemeikiran lebih baik waktu yang ada digunakan untuk bekerja mendapatkan uang daripada belajar di sekolah. Hal ini juga memengaruhi presensi kehadiran dan motivasi siswa untuk belajar di sekolah.

Kompetensi guru yang sangat memprihatinkan, guru yang mengajar memiliki keterbatasan dalam metode transfer pengetahuan yang digunakan karena ada 2 guru honorer, guru lulusan Universitas Terbuka dengan metode pembelajaran online sehingga tidak memiliki pengalaman dalam transfer pengetahuan, dan kompetensi guru akan bidang pelajaran yang diampunya. Hal ini nampak pada saat proses transfer pengetahuan terhadap siswa dengan menggunakan metode lama yang pernah didapatkannya saat sekolah dulu yaitu teacher oriented sehingga siswa SD saat ini memiliki ketergantungan pada kehadiran guru di kelas. Di lain pihak, karena ada beberapa kesibukan guru di luar sekolah seringkali guru tidak dapat hadir untuk memberikan pelajaran, alhasil jam pelajaran dibiarkan kosong dan siswa bermain di lapangan sekolah.

Kondisi ini sangatlah memprihatinkan jika kita berbicara dalam konteks revolusi industri 4.0 dan Making Indonesia 4.0 karena pendidikan dasar merupakan dasar dari pendidikan lanjutan, jika pendidikan dasar tidak kokoh maka akan sangat memengaruhi keberlangsungan pendidikan berikutnya.

\section{KESIMPULAN}

Kegiatan ini pada dasarnya bertujuan untuk mempersiapkan siswa kelas 4, 5 dan 6 dalam menghadapi ujian akhir dan Ujian Akhir Nasional. Pelaksanaan transfer pengetahuan Matematika dan Bahasa Inggris sangat dipengaruhi oleh metode pembelajaran yang diberikan oleh pihak sekolah. Metode pembelajaran yang diberikan bersifat teacher oriented sehingga proses pembelajaran sangat bergantung pada kehadiran dan proses transfer pengetahuan guru di kelas sedangkan kegiatan ini bersifat student oriented dengan metode drill dan ternyata terbukti dapat meningkatkan daya tangkap siswa. Hal ini nampak pada jawaban pertanyaan yang diberikan oleh siswa berdasarkan pola berpikir mereka dalam soal yang diberikan yang berupa nalar dan logika .

Kesimpulan dari kegiatan ini adalah metode transfer pengetahuan yang diterapkan sangat memengruhi proses belajar mengajar dan kemampuan daya tangkap siswa. Oleh karena itu, metode pembelajaran yang diberikan saat ini berupa student oriented sehingga transfer pengetahuan yang diberikan dapat sesuai dengan kebutuhan siswa.

Berakhirnya pelaksanaan kegiatan ini, pelaksana menemukan beberapa hal yang perlu ditanggulangi sebagai kelanjutan perkembangan pendidikan yaitu perlunya pembinaan guru terutama dalam metode pengajaran kepada siswa sehingga siswa dapat belajar sendiri tanpa ketergantungan pada kehadiran guru.

\section{UCAPAN TERIMA KASIH}

Tim pelaksana mengucapkan terima kasih atas dukungan penuh kepada Sekolah tinggi Ilmu Manajemen Shanti Bhuana baik melalui dana pengabdian masyarakat dan peminjaman peralatan. Kami juga mengucapkan terima kasih atas kerjasamanya SDN Tampe dan ketua umat gereja stasi St. Petrus yang telah memberi kesempatan pada kami untuk melayani dan menunaikan tugas pengabdian masyakat sebagai pelaksanaan tri dharma.

\section{DAFTAR PUSTAKA}

(BPPI), P. P. dan P. T. I. dan K. I. B. P. dan P. I. (2018). Kementerian Perindustrian Making Indonesia 4.0. Bengkayang, K. (2018). Neraca Pendidikan Daerah 2018. Hartarto. (2018). Making Indonesia 4.0.

Kabupaten Bengkayang, B. P. S. (2018). Statistik Daerah Kabupaten Bengkayang 2018. 
Kumalasari, E., Studi, P., Informatika, T., Teknik, F., \& Ponorogo, U. M. (2016). Perbedaan hasil belajar matematika siswa yang diajar dengan menggunakan metode drill dan ekspositori, 2(1), 21-28.

Menteri Desa, P. D. T. dan T. R. I. (2019). Keputusan Menteri Desa, Pembangunan Daerah Tertinggal dan Transmigrasi Republik Indonesia.

Presiden Republik Indonesia. (2015). Peraturan Presiden Republik Indonesia Nomor 131 tahun 2015. In Peraturan Presiden Republik Indonesia nomor 131 tahun 2015.

Rojko, A. (2017). Industry 4.0 Concept: Background and Overview. International Journal of Interactive Mobile Technologies (IJIM), 11(5), 77. https://doi.org/10.3991/ijim.v11i5.7072

Shahroom, A. A., \& Hussin, N. (2018). Industrial Revolution 4.0 and Education. International Journal of Academic Research in Business and Social Sciences, 8(9), 314-319. https://doi.org/10.6007/IJARBSS/v8-i9/4593

Su Luan, W., \& Abu Bakar, K. (2008). The Shift in the Role of Teachers in the Learning Process. European Journal of Social Sciences (Vol. 7).

Vasantan, P., Anggraeni, H., Sugianto, T., Science, M., School, H., Bhuana, S., ... Id, H. A. (2016). Knowledge Transfer Based Local Wisdom by Learning Method Buddy Program In District Bengkayang. International Journal of Multi Disipline Science (IJ-MDS) e-ISSN, 2615-1707. https://doi.org/10.26737/ij-mds.v1i1.413

Vasantan, P., \& Manggu, B. (2019). Social Learning Dayaknese Bakati' Rara In 3T region. Management Systems Development and Journals, l(1). 